\title{
SISTEM SARAAN DAN PENCEN ANGGOTA PERKHIDMATAN AWAM DI PERSEKUTUAN TANAH MELAYU, 1948-1970
}

\author{
Sharifah Darmia Sharif Adam \\ Ahmad Kamal Ariffin Mohd Rus
}

\begin{abstract}
Abstrak
Artikel ini membincangkan tentang sistem saraan dan pencen bagi anggota perkhidmatan awam yang berkhidmat di Persekutuan Tanah Melayu (PTM) antara tahun 1948 hingga 1970. Dalam tempoh tersebut, perbincangan difokuskan terhadap peranan pihak kerajaan British mahupun kerajaan PTM sendiri dalam usaha untuk melaksanakan pembaharuan atau penambahbaikan sistem saraan bagi anggota perkhidmatan awam yang dibuat berdasarkan tiga laporan semakan gaji. Dua laporan semakan gaji terhasil semasa di bawah pentadbiran kerajaan British iaitu Laporan Suruhanjaya Gaji Perkhidmatan Awam Malaya atau Laporan Trusted 1947 (Trusted Commission Report 1947) dan Laporan Jawatankuasa Khas Gaji di Persekutuan Malaya Benham 1950 atau Laporan Jawatankuasa Benham 1950(Benham Committee Report 1950). Manakala pada era pentadbiran kerajaan PTM pula terdapat satu laporan semakan gaji dikenali sebagai Laporan Suruhanjaya Diraja Mengenai Kajian Semula Gaji dan Syarat-syarat Perkhidmatan dalam Perkhidmatan Awam 1967 (Laporan Suffian 1967). Ketiga-tiga laporan suruhanjaya atau jawatankuasa untuk melaksanakan urusan semakan gaji bagi anggota perkhidmatan awam di PTM tersebut bukan sahaja memberi kesan terhadap struktur tangga gaji, skim perkhidmatan, syarat perkhidmatan, elaun, kemudahan tetapi juga persaraan dan faedah persaraan bagi anggota perkhidmatan awam. Oleh itu, berdasarkan hasil laporan ketiga-tiga suruhanjaya atau jawatankuasa tersebut kajian difokuskan untuk meneliti faedah dan manfaat yang diperoleh anggota perkhidmatan awam dari segi struktur tangga gaji, emolumen dan pencen. Selain itu, perbincangan turut menyentuh mengenai aspek pencen bagi anggota perkhidmatan awam yang dilihat dapat meningkatkan kefahaman mengenai pengaruh pencen dalam sistem saraan. Tinjauan mengenai sistem saraan adalah penting untuk menilai usaha kerajaan dalam melaksanakan perubahan yang dapat memberi faedah kepada anggota perkhidmatan awam di PTM.
\end{abstract}

\begin{abstract}
This article discusses about remuneration and retirement systems for civil servants in the Federation of Malaya (FM) between 1948 and 1970. During the period, discussions were focused on the role of the British government as well as the FM government itself in an effort to implement system reforms or improvements of remuneration for civil servants made based on three salary review reports. Two salary review reports were generated under the British government, report of the Trusted Commission Report 1947 and Benham Committee Report 1950. In the era of the administration of FM, there was a salary review report known as the Royal Commission Report on Salary Review and Terms of Service in the Civil Service 1967 (Suffian Report 1967). The three reports of committees or committees to carry out payroll review for civil servants in FM not only affect the structure of salaries, service schemes, terms of service, allowances, facilities but also retirement and retirement benefits for civil service members. Therefore, based on the results of the reports of the three commissions, the study focused on examining the benefits received by civil
\end{abstract}


service members in terms of the structure of salaries, emoluments and pensions. In addition, discussions also touch on aspects of pensions for civil service members who are seen to increase the understanding of the effects of pensions in the remuneration system. An overview of the remuneration system is important to evaluate the government's efforts in implementing changes that can benefit public service personnel in FM.

\section{Pengenalan}

Sistem saraan dan pencen bagi anggota perkhidmatan awam yang berkhidmat di Persekutuan Tanah Melayu (PTM) ${ }^{1}$ merupakan salah satu aspek yang mempunyai impak besar ke atas tranformasi anggota perkhidmatan awam. Pada tahun 1948 hingga 1970, usaha pihak kerajaan British mahupun kerajaan PTM sendiri untuk melaksanakan pembaharuan atau penambahbaikan sistem saraan bagi anggota perkhidmatan awam dapat dinilai berdasarkan laporan semakan gaji yang dilaksanakan sepanjang tempoh berkenaan. Dengan kata lain, perkembangan sistem saraan dapat ditinjau melalui penyusunan semula struktur perkhidmatan, pengubahsuaian syarat-syarat perkhidmatan dan pelarasan sistem saraan dan pencen yang dilaksanakan secara konvensional iaitu melalui beberapa urusan semakan gaji. ${ }^{2}$ Oleh itu, perbincangan mengenai sistem saraan akan dihuraikan berdasarkan dua laporan semakan gaji yang terhasil ketika di bawah pentadbiran kerajaan British iaitu Laporan Suruhanjaya Gaji Perkhidmatan Awam Malaya atau Laporan Trusted 1947 (Trusted Commission Report 1947) dan Laporan Jawatankuasa Khas Gaji di Persekutuan Malaya Benham 1950 atau Laporan Suruhanjaya Benham 1950 (Benham Committee Report 1950). Kemudian diikuti satu laporan semakan gaji yang terhasil semasa era pentadbiran kerajaan PTM dikenali sebagai Laporan Suruhanjaya Diraja Mengenai Kajian Semula Gaji dan Syarat-syarat Perkhidmatan dalam Perkhidmatan Awam 1967 (Laporan Suffian 1967). Selain itu, perbincangan turut menyentuh mengenai aspek pencen bagi anggota perkhidmatan awam yang dilihat dapat melengkapkan kefahaman mengenai pengaruh pencen dalam sistem saraan.

\section{Sistem Saraan di bawah Laporan Suruhanjaya Gaji Perkhidmatan Awam Malaya 1947 (Trusted Commission Report 1947)}

Di bawah pentadbiran kerajaan British antara tahun 1948 hingga 1956 dapat dilihat dengan jelas kaitan aspek sistem saraan terhadap perkembangan perkhidmatan awam di PTM. Perkara ini terbukti apabila dalam tempoh selama sembilan tahun tersebut terdapat dua laporan semakan gaji yang dilaksanakan oleh kerajaan British sebagai usaha untuk menambahbaik skim perkhidmatan bagi anggota perkhidmatan awam di PTM. Laporan yang pertama adalah Laporan Suruhanjaya Perkhidmatan Awam Malaya 1947 atau Laporan Trusted 1947 (Trusted Commission Report 1947). ${ }^{3}$ Walaupun jawatankuasa semakan gaji tersebut ditubuhkan pada tahun 1947 dan laporan dikeluarkan secara rasmi pada 9 Disember $1947^{4}$ tetapi pelaksanaan rancangan-rancangan yang terdapat dalam laporan tersebut dilaksanakan sehingga Laporan Jawatankuasa Khas Gaji di Persekutuan Malaya Benham 1950 diwujudkan sekali gus membolehkan laporan tersebut termasuk dalam skop perbincangan. Suruhanjaya Perkhidmatan Awam Malaya 1947 dipengerusikan oleh Sir Harry Trusted $^{5}$ yang bertanggungjawab dalam melaksanakan semakan gaji bagi anggota 
perkhidmatan awam di PTM. Ketika itu, semakan gaji bagi anggota perkhidmatan awam PTM dibuat disebabkan oleh kenaikan ketara dalam kos sara hidup selepas Perang Dunia Kedua. Secara keseluruhannya, jawatankuasa semakan gaji ini dibuat berdasarkan tujuan seperti berikut:

a). Untuk menimbang dan menerima syor untuk semakan gaji, emolumen dan syarat perkhidmatan semula pegawai-pegawai awam di Singapura dan Tanah Melayu.

b). Untuk menimbangkan sejauh mana kos sara hidup yang patut dimasukkan dalam asas gaji dengan mengambil kira keadaan ekonomi yang belum stabil ketika itu kesan Perang Dunia Kedua.

c). Untuk terus merangka syor-syor, mengurangkan kepelbagaian semasa gaji skala dan syarat perkhidmatan dalam pelbagai gred perkhidmatan awam.

d). Untuk mengambil tindakan sebagaimana yang sewajarnya bagi memastikan cadangan Suruhanjaya Gaji Perkhidmatan Awam Malaya 1947 akan berkaitan dengan Suruhanjaya Gaji Hong Kong yang tujuan khususnya untuk memudahkan pertukaran pegawai antara Tanah Melayu dan wilayah British di Borneo.

e). Untuk membuat syor mengenai kemasukan pegawai yang sedang berkhidmat dalam mana-mana skala gaji baru atau disemak semula.

f). Untuk mempunyai kaitan secara umum dalam kertas putih, Kolonial No. 197, 1946 yang berkaitan dengan organisasi perkhidmatan penjajah. $^{6}$

Penerbitan laporan jawatankuasa tersebut membuktikan bahawa kerajaan British berusaha mencari penyelesaian supaya anggota perkhidmatan awam di PTM khususnya tidak terjejas akibat kemerosotan ekonomi yang diakibatkan oleh peperangan. Hal ini penting kerana kesukaran hidup akibat masalah ekonomi akan menyebabkan prestasi kerja anggota perkhidmatan awam menurun seterusnya akan memberi kesan terhadap kelancaran urusan pentadbiran kerajaan British. Melalui Laporan Suruhanjaya Gaji Malaya 1947, kerajaan British memberi tanggungjawab kepada suruhanjaya tersebut untuk mengkaji dan memperbaiki semula kadar pemberian gaji asas, emolumen dan syarat perkhidmatan untuk anggota perkhidmatan awam supaya bersesuaian dengan keadaan peningkatan kos sara hidup ketika itu. Hasil laporan tersebut, anggota pekhidmatan awam menerima kenaikan gaji [sebanyak 10 peratus] berdasarkan gaji asas mereka iaitu bagi gaji asas kurang $\$ 500$ sebulan mendapat kenaikan $\$ 50$, bagi pegawai yang gaji asas antara $\$ 500$ hingga $\$ 1000$ menerima $\$ 75$ dan bagi yang mendapat gaji $\$ 1000$ ke atas sebulan akan menerima $\$ 100 .^{7}$

Apa yang penting adalah penambahbaikan gaji bukan sahaja menjamin keselesaan hidup kepada anggota perkhidmatan awam tetapi juga secara langsung meningkatkan faedah persaraan yang mereka terima. Antara syor penting yang terkandung dalam laporan suruhanjaya ini adalah cadangan supaya tempoh yang berbeza-beza bagi pegawai-pegawai untuk berkhidmat di bawah skim yang berlainan sebelum mereka berpencen hendaklah diseragamkan. ${ }^{8}$ Hal ini adalah untuk menjamin semua anggota perkhidmatan awam yang berkhidmat dalam pelbagai bahagian mendapat pencen atau faedah persaraan yang sewajarnya. Selain itu, suruhanjaya juga menjalankan semakan gaji yang memperlihatkan perbandingan dibuat antara gaji anggota perkhidmatanawam dengan kakitangan sektor swasta, penetapan elaun kos 
sara hidup yang lebih sesuai untuk dicantumkan ke dalam gaji bersih dan pengurangan bilangan tangga gaji yang sedia ada dalam sektor awam. ${ }^{9}$

Tinjauan berkenaan perkara-perkara terbabit membawa perubahan secara langsung dalam aspek faedah persaraan atau pencen yang akan dinikmati setelah anggota perkhidmatan awam bersara. Dengan erti kata lain, semakan gaji oleh suruhanjaya berkenaan adalah untuk meningkatkan jumlah gaji dan elaun anggota perkhidmatan awam di PTM. Pelaksanaan kajian terhadap perbezaan jumlah gaji yang diterima antara anggota perkhidmatan awam dengan kakitangan swasta bermatlamat untuk menambah baik keadaan gaji anggota perkhidmatan awam supaya dapat menarik lebih ramai calon untuk menyertai perkhidmatan awam. Malahan suruhanjaya ini juga berusaha untuk memperbaiki kadar elaun anggota perkhidmatan awam supaya mencukupi keperluan selaras dengan peredaran zaman. Hasil laporan semakan gaji tersebut digunakan oleh kerajaan British sebagai garis panduan dan rujukan untuk menambah baik struktur sistem saraan anggota perkhidmatan awam.

\section{Sistem Saraan di bawah Laporan Jawatankuasa Khas Gaji di Persekutuan Malaya Benham, 1950 (Benham Committee Report 1950)}

Pada 12 Julai 1948, kerajaan British mengisytiharkan darurat akibat huru hara yang dicetuskan oleh pihak komunis. Keadaan ini menyebabkan ia menjadi perkara utama yang perlu ditangani oleh pihak kerajaan British di PTM. Namun, pada masa yang sama juga didapati kerajaan British masih memberi tumpuan terhadap perkara-perkara yang berkaitan dengan gaji bagi anggota awam. Hal tersebut terbukti apabila pada bulan Ogos 1949, Majlis Perundangan Persekutuan melantik jawatankuasa khas semakan gaji dikenali sebagai Laporan Jawatankuasa Khas Gaji di Persekutuan Malaya Benham, 1950 atau Laporan Jawatankuasa Benham 1950 (Benham Committee Report 1950) untuk menyemak semula tangga gaji anggota perkhidmatan awam. ${ }^{10}$ Jawatankuasa berkenaan dipengerusikan oleh F.C. Benham dan ahli jawatankuasa lain terdiri daripada Dato' Onn bin Jaafar, Khoo Teik Ee, Dato' E.E.C. Thuraisingham, Dato' Haji Mohamed Eusoff bin Mohamed Yusoff (Dato' Muda Panglima Kinta), Mohamed Salleh bin Hakim, H.H. Facer, M.V. del Tufo dan E.B. David. ${ }^{11}$ Laporan Jawatankuasa Khas Gaji di Persekutuan Malaya Benham, 1950 diterbitkan pada bulan September $1950 .^{12}$

Secara lebih terperinci, tujuan penubuhan Jawatankuasa Khas Gaji di Persekutuan Malaya Benham, 1950 adalah seperti berikut:

a. Untuk menimbangkan dan mengesyorkan tangga gaji yang lebih adil kepada semua kakitangan awam yang berkhidmat dalam pelbagai bahagian dan jabatan dalam Perkhidmatan Awam Persekutuan Tanah Melayu.

b. Untuk membuat syor yang lebih khusus mengenai tangga gaji yang lebih sesuai kepada pekerja wanita. ${ }^{13}$

Hasilnya menunjukkan bahawa Jawatankuasa Benham bukan sahaja menyemak ketidakadilan yang wujud dari segi tangga gaji yang digunapakai untuk semua anggota perkhidmatan awam di PTM tetapi juga mengesyorkan cara pemindahan anggota perkhidmatan awam yang lebih adil. Hal ini bermakna melalui Laporan Jawatankuasa Khas Gaji di Persekutuan Malaya Benham, 1950 semakan semula tangga gaji bagi anggota perkhidmatan awam diselaraskan mengikut bidang tugas dan tanggungjawab yang dipikul oleh anggota tersebut. Dengan kata lain, Jawatankuasa Benham lebih tertumpu kepada menyelaraskan skim gaji pelbagai perkhidmatan 
secara berkumpulan di bawah kumpulan pekerjaan, skala masa yang ditentukan sebagaimana yang dinyatakan dalam petikan berikut:

(i)The salary should be related to the minimum entrance qualification required in the grade, the kind of work to be done and the length and type of training required during the initial probationary period (ii) the salary to be drawn at the completion of the probationery period should be related to the standard of training which the probationer must receive (iii) the maximum of the time scale should be related to the duties and responsibilities of the officers concerned and also to the minimum standard necessary to pass the examination and the efficiency bars (iv) the length of the time scale should be such that and officer whose service is satisfactory would reach the maximum between the ages of 40 and $45 .^{14}$

Oleh itu, jelaslah bahawa penyelarasan tangga gaji tersebut menyebabkan semua anggota perkhidmatan awam mendapat faedah persaraan yang lebih baik berikutan peningkatan gaji asas mereka. Di samping itu, anggota perkhidmatan awam akan menerima keseluruhan saraan bersama-sama dengan gaji pokok anggota perkhidmatan awam tersebut termasuklah elaun kos sara hidup dan elaun perumahan. ${ }^{15}$ Keadaan ini membolehkan anggota perkhidmatan awam menikmati taraf hidup yang lebih berkualiti walaupun setelah bersara kelak.

Pada masa sama juga, terdapat satu lagi perkembangan menarik yang didapati melalui Laporan Jawatankuasa Benham, 1950 iaitu terhasilnya syor-syor berkaitan dengan tangga gaji bagi anggota wanita yang berkhidmat dalam perkhidmatan awam. Hal ini kerana Jawatankuasa Benham 1950 menyemak semula tangga gaji bagi anggota wanita dalam perkhidmatan awam yang dibuat dalam Laporan Jawatankuasa Suruhanjaya Gaji Malaya 1947 dan kemudian mengesyorkan bahawa perlunya anggota wanita diberikan tangga gaji yang lebih sesuai iaitu sama dengan anggota lelaki. ${ }^{16}$ Persamaan gaji tersebut penting memandangkan terdapat anggota wanita yangberkhidmat dalam bidang tugas dan memikul tanggungjawabyang sama dengan anggota lelaki. ${ }^{17}$ Oleh yang demikian, pelaksanaan tangga gaji yang sama dilihat akan mewujudkan keadilan kepada anggota wanita. Sebenarnya, terdapat beberapa bidang perkhidmatan sahaja yang menuntut persamaan tangga gaji antara anggota lelaki dan wanita tetapi syor-syor yang berkaitan tangga gaji wanita memberikan kesan positif terhadap perkembangan perkhidmatan awam di PTM. Hal ini kerana persamaan tangga gaji antara kedua jantina ini bermakna faedah yang akan diterima mereka selepas bersara juga akan dapat dinikmati secara adil. Oleh itu, dapatlah dinyatakan bahawa secara umumnya, jawatankuasa tersebut ditubuhkan untuk memperbaiki kelemahan yang terdapat dalam Laporan Suruhanjaya Gaji Malaya 1947. Di samping itu, pihak kerajaan kolonial British telah menggunakan syor-syor daripada Laporan Jawatankuasa Benham 1950 mengantikan syor-syor yang terdapat dalam Laporan Suruhanjaya Gaji Malaya 1947 sebagai rujukan untuk perkara yang melibatkan gaji dan sistem saraan anggota perkhidmatan awam di PTM sehinggalah pada tahun 1967. 


\section{Sistem Saraan di bawah Laporan Suruhanjaya diRaja Mengenai Kajian Semula Gaji dan Syarat-syarat Perkhidmatan dalam Perkhidmatan Awam 1967 (Laporan Suffian 1967)}

Di bawah pentadbiran kerajaan PTM, hal mengenai gaji telah mendapat perhatian kerajaan. Hal ini terbukti dalam manifesto Parti Perikatan iaitu parti yang berjaya membentuk kerajaan di PTM menyebut bahawa adalah menjadi dasar kerajaan Perikatan untuk berterusan memastikan semua pekerja dibayar secukupnya dan langkah berunding akan diambil untuk mencapai tujuan tersebut. ${ }^{18}$ Selain itu, kerajaan Perikatan juga akan membuat semula semakan tangga gaji supaya semua anggota perkhidmatan awam mendapat gaji yang adil. ${ }^{19}$ Namun demikian, semakan gaji tersebut hanya dibentuk pada tahun 1967 dikenali sebagai Laporan Suruhanjaya diRaja Mengenai Kajian Semula Gaji dan Syarat-syarat Perkhidmatan dalam Perkhidmatan Awam 1967 (Laporan Suffian 1967). Jawatankuasa suruhanjaya tersebut dipengerusikan oleh Hakim Mohamed Suffian ${ }^{20}$ dan merupakan semakan gaji pertama yang dilaksanakan di bawah pentadbiran kerajaan PTM.

Walau bagaimanapun, perlu dijelaskan bahawa sebenarnya suruhanjaya tersebut telah ditubuhkan lebih awal iaitu pada 26 Februari 1964 dengan tujuan untuk mengkaji semula syarat-syarat perkhidmatan anggota perkhidmatan awam di PTM termasuklah anggota perkhidmatan awam yang berkhidmat sebagai guru. Namun, ketika itu, semakan tersebut tidak melibatkan anggota perkhidmatan awam yang berkhidmat dalam angkatan tentera. Kemudian, pada bulan April 1964, kajian terhadap syarat perkhidmatan bagi guru-guru bukan lagi di bawah tugas Suruhanjaya diRaja Suffian kerana sebuah suruhanjaya khas telah ditubuhkan dikenali sebagai Suruhanjaya diRaja Aziz untuk mengkaji perkara tersebut. ${ }^{21}$ Hal ini menunjukkan dengan jelas bahawa kerajaan sentiasa bersikap proaktif dalam mewujudkan suruhanjaya bagi membuat kajian atau semakan gaji dan syarat-syarat perkhidmatan yang bertujuan untuk meningkatkan kualiti perkhidmatan awam di PTM.

Sebenarnya, Laporan Suruhanjaya diRaja Suffian 1967 sangat penting dalam melihat perubahan dan perkembangan yang berlaku dalam sistem saraan anggota perkhidmatan awam di PTM kerana antara perkara utama yang disyorkan oleh suruhanjaya tersebut adalah mengenai penyatuan dan penyelarasan semula sistem saraan sektor awam bagi keseluruhan perkhidmatan awam. ${ }^{22}$ Oleh itu, pada 3 Julai 1967, Suruhanjaya diRaja Suffian mengemukakan cadangan berkaitan dengan faedah persaraan untuk dipertimbangkan oleh kerajaan. ${ }^{23}$ Setelah kerajaan membuat pertimbangan sewajarnya, cadangan dalam laporan tersebut diterima dan faedah persaraan tersebut dilaksanakan pada 1 Januari 1970 tetapi secara lebih khusus cadangan atau syor-syor tersebut dilaksanakan mulai tarikh berikut:

a. Bulan Mei bagi pekerja-pekerja yang dahulunya dalam Bahagian IV, pekerja perusahaan dan buruh kasar. Untuk maksud faedah persaraan, pekerja-pekerja yang meninggal dunia atau bersara pada atau selepas 1 Ogos 1968 tetapi sebelum 1 Mei 1969 akan dianggap telah menerima gaji bersih mulai 1 Ogos $1968^{24}$ yang bermakna faedah persaraan mereka akan dibuat mengikut gaji bersih mereka.

b. Bulan November bagi lain-lain pekerja sektor awam di Persekutuan Tanah Melayu.

Pelaksanaan cadangan atau syor yang terkandung dalam Laporan Suruhanjaya diRaja Suffian menyebabkan perubahan yang besar terhadap sistem saraan bagi anggota perkhidmatan awam di PTM. Hal ini dapat dilihat melalui kewujudan prinsip-prinsip ke atas perkhidmatan awam sebagaimana yang berikut: 
a. Kakitangan awam akan dibayar gaji bersih berasaskan prinsip "rate for the job”. Gaji bersih tersebut merupakan satu pembayaran tanpa elaun sara hidup dan elaun perumahan yang dibayar sebelumnya.

b. Pembahagian kakitangan awam ditukar daripada 'bahagian' kepada 'kumpulan' dan dibuat berasaskan gaji maksima bagi tangga gaji yang berkenaan. Sebagai contohnya adalah seperti Jadual 1 berikut:

Jadual 1: Kumpulan Anggota Perkhidmatan Awam Mengikut Gaji Maksima

\begin{tabular}{|l|l|}
\hline \multicolumn{1}{|c|}{ Kumpulan } & \multicolumn{1}{c|}{ Gaji Maksima } \\
\hline Kumpulan Pengurusan dan Ikhtisas & Melebihi \$1,250 sebulan \\
\hline Kumpulan Kerja dan Separa Ikhtisas & $\begin{array}{l}\text { Melebihi \$700 Sebulan tetapi tidak melebihi } \\
\$ 1,250 \text { sebulan }\end{array}$ \\
\hline Kumpulan Pengkeranian dan Teknik & $\begin{array}{l}\text { Melebihi \$200 sebulan tetapi tidak melebihi } \\
\text { \$700 sebulan }\end{array}$ \\
\hline $\begin{array}{l}\text { Kumpulan Pekerja-pekerja Perusahaan dan } \\
\text { Buruh Kasar }\end{array}$ & \begin{tabular}{l} 
Selain daripada golongan di atas \\
\hline
\end{tabular} \\
\hline
\end{tabular}

Sumber: Lapuran Kedua Jawatankuasa Khas Mengkaji Dasar-dasar Faedah Persaraan Pekerjapekerja dalam Perkhidmatan Awam dan Badan-badan Berkanun, Penggal I, November, 1973, h. 27.

c. Pembahagian pekerja mengikut taraf dan gred turut diubah seperti perkhidmatan kerani yang dahulunya terbahagi kepada tingkatan biasa, khas dan tertinggi telah ditukar menjadi Perkhidmatan Kerani Rendah dan Perkhidmatan Kerani Am Gred I, II dan III. Sementara itu, pegawai-pegawai kerani yang dahulunya memegang jawatan Tingkatan Tertinggi telah digredkan semula sebagai pekerja-pekerja Kumpulan Kerja dan Separa Ikhtisas. ${ }^{25}$

Perbincangan lanjut mengenai persaraan dan pencen bagi anggota perkhidmatan awam di PTM terkandung dalam Bab X Laporan Suruhanjaya diRaja Suffian. Apa yang menariknya adalah perbincangan suruhanjaya tersebut berjaya menghasilkan beberapa cadangan yang membawa perubahan kepada sistem persaraan atau pencen bagi anggota perkhidmatan awam di PTM. Antara cadangan tersebut adalah supaya disatukan ketiga-tiga ordinan pencen yang digunakan di Semenanjung Tanah Melayu, Sabah dan Sarawak sebagaimana yang dilakukan pada tahun 1951 apabila tujuh ordinan dan enakmen pencen yang berasingan di negeri-negeri Tanah Melayu disatukan di bawah Ordinan Pencen 1951. ${ }^{26}$ Tindakan penyatuan ordinan pencen tersebut dilihat perlu untuk menyeragamkan sistem saraan bagi anggota perkhidmatan awam seterusnya mewujudkan sistem saraan yang lebih adil dan telus.

Selain itu, Suruhanjaya diRaja Suffian turut memberi perhatian terhadap salah satu aspek penting dalam sistem saraan iaitu pencen. Berhubung soal pencen tersebut, Suruhanjaya diRaja Suffian mencadangkan supaya pencen tidak seharusnya dijadikan hak. ${ }^{27}$ Hal ini disebabkan suruhanjaya berpendapat bahawa pengurniaan pencen hendaklah terus dijadikan sebagai satu kelayakan sahaja bagi anggota perkhidmatan 
awam dan bukannya hak mutlak (absolutely right). ${ }^{28}$ Malahan, dicadangkan juga supaya faktor pencen disusutkan daripada satu per enam ratus (1/600) gaji bersih kepada satu per lapan ratus (1/800) gaji bersih pendapatan berpencen tahunan. Hal ini kerana suruhanjaya mengesyorkan bahawa keseluruhan gaji bersih hendaklah dijadikan gaji berpencen dan perkiraan pencen ke atasnya hendaklah mengikut faktor yang disusutkan daripada satu per enam ratus (1/600) gaji bersih kepada maksimum satu per lapan ratus (1/800) gaji bersih tertakluk kepada separuh pendapatan tahunan seseorang kakitangan awam itu. ${ }^{29}$ Sebenarnya, penyusutan pencen dibuat kerana terdapat perubahan saiz perkhidmatan awam di PTM yang dilihat semakin membesar akibat perkembangan pesat ekonomi negara. Oleh itu, Suruhanjaya diRaja Suffian berpendapat bahawa kerajaan tidak berkemampuan untuk membayar pencen anggota perkhidmatan mengikut gaji bersih sekiranya pencen tersebut terus dikira mengikut faktor satu per enam ratus (1/600) gaji bersih. Rentetan itu, Suruhanjaya diRaja Suffian mengesyorkan bahawa adalah lebih baik faktor pencen anggota perkhidmatan awam disusutkan kepada satu perlapan ratus (1/800) tertakluk kepada separuh pendapatan tahunan seseorang kakitangan awam itu. ${ }^{30}$ Melalui perubahan tersebut, Suruhanjaya diRaja Suffian menjangkakan bahawa kesemua anggota perkhidmatan awam di PTM akan memperoleh pencen yang lebih lumayan.

Namun, jangkaan tersebut meleset apabila didapati lebih kurang 37,000 orang anggota perkhidmatan awam khususnya anggota yang berkhidmat dalam Bahagian III mendapat pencen yang lebih kecil daripada kelayakan mereka sebelum sistem gaji tersebut dilaksanakan. ${ }^{31}$ Hal ini disebabkan tidak semua kenaikan gaji di bawah sistem gaji baharu tersebut seimbang dengan kadar susutan yang dikenakan terhadap faktor perkiraan pencen. Selain itu, ia juga disebabkan pemberhentian pengurniaan elaun sara hidup kepada pesara-pesara awam. Sebenarnya, sebelum sistem gaji yang disyorkan oleh Suruhanjaya diRaja Suffian dilaksanakan, pesara-pesara awam di PTM diberikan elaun sara hidup mengikut kadar yang dibekalkan di bawah Pekeliling FEO. Bil. 21/1956. ${ }^{32}$ Pemberian elaun tersebut merupakan kebaikan kepada pesara-pesara awam kerana menambahkan lagi jumlah faedah bulanan yang diterima oleh mereka. Namun begitu, melalui pelaksanaan sistem gaji yang disyorkan oleh Suruhanjaya diRaja Suffian, elaun sara hidup tersebut tidak lagi diberikan kepada pesara-pesara awam sekali gus mengurangkan jumlah faedah persaraan yang dinikmati sebelum ini. Oleh itu, untuk penjelasan lanjut berkenaan hal tersebut, Jadual 2 menunjukkan perbandingan kadar pencen pesara-pesara awam bagi empat perkhidmatan seperti berikut: 


\section{Jadual 2: Perbandingan Kadar Pencen Pesara-pesara Awam Bagi Empat} Perkhidmatan

\begin{tabular}{|c|c|c|c|}
\hline Pekerjaan & & Sebelum Gaji Bersih & $\begin{array}{c}\text { Sesudah Gaji } \\
\text { Bersih } \\
\text { (Suruhanjaya } \\
\text { Suffian) }\end{array}$ \\
& & & $1,800.00$ \\
& & $1,254.00$ & $33,750.00$ \\
& Gaji Bulanan & $31,350.00$ & 675.00 \\
& Pencen Gantian Tetap & 627.00 & - \\
& Pencen Bulanan & - & 675.00 \\
\hline 2. Pegawai Tadbir dan & Elaun Sara Hidup & 627.00 & 1000.00 \\
& Jumlah Pencen Bulanan & 700.00 & $18,750.00$ \\
& Gaji Bulanan & $17,500.00$ & 375.00 \\
& Pencen Gantian Tetap & 350.00 & - \\
& Pencen Bulanan & 45.00 & 375.00 \\
\hline Elawai Kerja & Elaun Sara Hidup & 395.00 & 800.00 \\
& Jumlah Pencen Bulanan & 535.00 & $15,000.00$ \\
& Gaji Bulanan & $13,375.00$ & 300.00 \\
& Pencen Gantian Tetap & 267.00 & - \\
& Pencen Bulanan & 55.00 & 300.00 \\
\hline Eegawai Kerani Am & Elaun Sara Hidup & 322.50 & 1000.00 \\
& Jumlah Pencen Bulanan & 765.00 & $18,750.00$ \\
& Gaji Bulanan & $19,125.00$ & 375.00 \\
& Pencen Gantian Tetap & 382.50 & - \\
& Pencen Bulanan & 28.50 & 375.00 \\
\hline & Elaun Sara Hidup & 411.00 & \\
\hline
\end{tabular}

Sumber: Lapuran Kedua Jawatankuasa Khas Mengkaji Dasar-dasar Faedah Persaraan Pekerjapekerja dalam Perkhidmatan Awam dan Badan-badan BerkanunPenggal I, November, 1973.

Berdasarkan Jadual 2, jelaslah bahawa pelaksanaan sistem gaji mengikut cadangan Suruhanjaya diRaja Suffian menyebabkan terdapat sebilangan anggota perkhidmatan awam khususnya yang berkhidmat di peringkat bawahan menerima pencen yang lebih kecil melalui sistem gaji bersih berbanding sebelumnya. Hal ini jelas dapat dilihat apabila anggota perkhidmatan awam yang berkhidmat sebagai pegawai kerja, pegawai kerani am dan pembantu teknik menerima jumlah pencen bulanan yang besar semasa elaun sara hidup masih diberikan kepada mereka. Sementara itu, Pegawai Tadbir dan Diplomatik pula walaupun tidak mendapat elaun sara hidup tetapi mereka menerima manfaat kenaikan jumlah pencen bulanan.

Sebenarnya, Suruhanjaya diRaja Suffian mengesyorkan supaya elaun sara hidup tidak seharusnya dibayar kepada mana-mana anggota perkhidmatan awam yang berpencen ${ }^{33}$ kerana berpendapat bahawa sistem gaji bersih yang disyorkan sebagai salah satu usaha kerajaan untuk memperbaiki sistem gaji anggota perkhidmatan awam yang sebelum ini telahpun memberikan gaji yang lumayan kepada anggota perkhidmatan awam di PTM. Pemberian gaji yang lumayan pula dianggap akan turut memberikan pencen yang lumayan. Oleh itu, Suruhanjaya diRaja Suffian berpendapat elaun sara hidup tidak lagi perlu dibayar kepada mana-mana pesara berpencen yang tertakluk di bawah sistem gaji baharu. Jika diperhalusi, pelaksanaan sistem gaji tersebut memberikan kesan negatif kepada anggota perkhidmatan awam terutamanya yang berkhidmat di peringkat rendah kerana terpaksa menanggung kos kenaikan barang-barang keperluan akibat kejatuhan mutu pembelian pencen mereka. 
Pada masa yang sama, Suruhanjaya diRaja Suffian juga mengesyorkan supaya Skim Pencen Balu-balu dan Anak-anak Yatim yang digunapakai sebelum itu digantikan dengan Skim Pencen Keluarga Bercarum bagi semua anggota perkhidmatan awam. ${ }^{34}$ Penggantian skim tersebut dibuat atas pertimbangan bahawa terdapat rasa tidak puas hati kerana hanya sebilangan kecil iaitu sejumlah 8,380 orang sahaja yang menjadi ahlinya dengan 4,410 orang yang mendapat faedah keluarga terlindung di bawah skim tersebut. ${ }^{35}$ Berdasarkan situasi tersebut, Suruhanjaya diRaja Suffian mengambil langkah untuk memperkenalkan satu skim baharu yang lebih baik. Namun begitu, apabila Skim Balu-balu dan Anak-anak Yatim berkenaan ditamatkan, ia tidak diganti serta merta dengan skim yang dicadangkan oleh Suruhanjaya diRaja Suffian kerana skim yang dicadangkan tersebut belum lagi diwujudkan. Sebaliknya, ia digantikan dengan Skim Pencen Terjamin yang hanya bersifat sementara sahaja. Di bawah Skim Pencen Terjamin, pencen yang layak diberikan kepada seseorang pesara awam adalah dijamin pembayarannya selama tempoh dua belas setengah tahun mulai tarikh persaraan atau kematian kakitangan tersebut. Oleh itu, jika seseorang anggota perkhidmatan awam meninggal dunia setahun selepas tarikh persaraannya bermula, maka pencennya akan terus dibayar kepada keluarganya selama sebelas setengah tahun lagi yang dinamakan 'Pencen Terbitan'. Sementara itu, jika seseorang anggota perkhidmatan awam meninggal dunia semasa dalam perkhidmatan setelah berkhidmat tidak kurang daripada sepuluh tahun, pencen yang layak dikurniakan kepada anggota tersebut akan dibayar kepada keluarganya selama tempoh dua belas setengah tahun mulai pada tarikh kematiannya. ${ }^{36}$ Justeru, nyatalah bahawa skim-skim berkenan bukan sahaja memberikan pembelaan yang sewajarnya kepada anggota perkhidmatan awam yang meninggal dunia tetapi juga dalam masa yang sama turut melindungi keluarga mereka.

Berdasarkan perbincangan terhadap ketiga-tiga semakan gaji yang dilaksanakan sepanjang tempoh antara tahun 1948 hingga 1970 menjelaskan bahawa sejak sebelum mencapai kemerdekaan sehinggalah selepas mencapai kemerdekaan pihak kerajaan sentiasa berusaha untuk memastikan semua anggota perkhidmatan awam menerima gaji yang berpatutan dan menikmati pakej saraan sepanjang hayat mereka. ${ }^{37}$ Tanggungjawab tersebut dipikul oleh Jabatan Perkhidmatan Awam (JPA) sebagai institusi yang berperanan penting dalam memikul tugas bagi memastikan semua anggota perkhidmatan awam di PTM menikmati faedah persaraan apabila mencapai umur bersara. Peranan JPA dalam urusan sistem saraan dapat dilihat melalui peranan Ketua Pengarah Perkhidmatan Awam yang merupakan Setiausaha Mesyuarat Jawatankuasa Kabinet Mengenai Perjawatan dan Gaji Pekerja-pekerja Sektor Awam bagi mendapatkan keputusan kerajaan berkaitan penyemakan gaji, syarat-syarat perkhidmatan serta pewujudan elaun-elaun dan kemudahan bagi anggota sektor awam. ${ }^{38}$ Penambahbaikan yang berlaku melalui semakan gaji menunjukkan penghargaan kerajaan terhadap anggota perkhidmatan awam di atas tenaga dan sumbangan yang besar terhadap pelaksanaan dasar kerajaan dan pembangunan negara.

\section{Sistem Saraan dalam Aspek Pencen}

Selain aspek gaji, pencen merupakan salah satu aspek yang perlu dibincangkan dalam tinjauan mengenai sistem saraan bagi anggota perkhidmatan awam di PTM. Walaupun Laporan Suffian 1967 menyentuh mengenai pencen tetapi adalah perlu tinjauan lebih mendalam dibuat bagi melengkapkan kefahaman mengenai pengaruh 
pencen dalam sistem Saraan. Pencen boleh ditakrifkan sebagai pengurniaan penghargaan kepada seorang anggota perkhidmatan awam di atas perkhidmatannya yang lama dan baik atau dengan erti kata lain pencen adalah pengurniaan wang kala masa (periodical payment) bulanan. ${ }^{39}$ Seseorang anggota perkhidmatan awam layak menerima pencen berdasarkan perkhidmatan lamanya sebagaimana yang dijelaskan dalam Ordinan Pencen, 1951. ${ }^{40}$ Dalam ordinan tersebut, seorang anggota perkhidmatan awam hendaklah berkhidmat tidak kurang daripada 33 1/3 tahun atau selama 400 bulan untuk melayakkannya menerima pencen setengah (dua pertiga sebelum gaji bersih) daripada gaji tertingginya. ${ }^{41}$ Namun, sekiranya seseorang anggota perkhidmatan awam berkhidmat kurang daripada tempoh tersebut, pencen yang dikurniakan kepadanya adalah seimbang dengan tempoh perkhidmatannya. Manakala jika anggota perkhidmatan awam berkhidmat melebihi tempoh yang ditetapkan oleh Ordinan tersebut, pencen yang diberikan kepadanya tidak akan melebihi kadar yang dinyatakan. ${ }^{42}$ Dengan kata lain, walaupun seseorang kakitangan itu berkhidmat melebihi tempoh yang ditetapkan dalam Ordinan Pencen 1951, ia tidak membawa sebarang tambahan ke atas faedah persaraan anggota perkhidmatan awam tersebut.

Sementara itu, dalam konteks PTM, pencen bukanlah suatu ganjaran, hadiah ataupun keistimewaan yang dijamin dan dilindungi secara mutlak oleh Perlembagaan PTM. Oleh itu, Parlimen mempunyai kuasa untuk meminda mana-mana undangundang mengenai pencen. ${ }^{43}$ Walau bagaimanapun, menurut Perkara 147 dalam Perlembagaan PTM, pencen dijamin sebagai suatu hak hanya dalam keadaan-keadaan berikut:

"147 (1) Undang-undang yang dipakai bagi mana-mana pencen, gratuiti atau elaun lain (dalam perkara ini dinamakan anugerah) yang diberi kepada mana-mana ahli perkhidmatan awam, atau kepada balunya, anaknya, tanggungannya atau wakil peribadinya, ialah undang-undang yang dipakai pada tarikh yang berkenaan atau manamana undang-undang yang dibuat kemudiannya dimana faedah yang orang itu boleh mendapat tidaklah boleh kurang daripada apa yang ia berhak." 44

Tarikh yang dimaksudkan dalam petikan tersebut adalah merangkumi tarikh seperti berikut:

a. Bagi pencen atau anugerah yang dibuat sebelum hari merdeka, ialah tarikh anugerah itu dibuat.

b. Bagi anugerah yang dibuat selepas hari merdeka, mana-mana ahli perkhidmatan awam yang telah menjadi ahli perkhidmatan awam sebelum hari merdeka, tarikh berkenaan ialah pada 30 Ogos 1957.

c. Mengenai anugerah yang diberikan kepada mana-mana orang yang menjadi ahli mana-mana perkhidmatan awam pada atau selepas hari merdeka, tarikhnya ialah pada tarikh ia menjadi ahli. ${ }^{45}$

Oleh itu, jelaslah bahawa pencen yang diberikan kepada anggota perkhidmatan awam di PTM boleh berubah mengikut perkembangan undang-undang semasa. Sungguhpun demikian, pencen yang diperoleh oleh seseorang anggota perkhidmatan awam tetap akan dibuat dengan sewajarnya tanpa menafikan hak mana-mana pihak yang terbabit.

\section{Pelantikan Anggota Perkhidmatan Awam dalam Jawatan Berpencen}

Secara umumnya, setiap anggota perkhidmatan awam yang pertama kali dilantik memegang jawatan berpencen dalam perkhidmatan awam biasanya diwajibkan untuk 
melalui satu tempoh percubaan iaitu selama tiga tahun. Tempoh percubaan tersebut penting untuk melayakkan seseorang anggota perkhidmatan awam disahkan dalam jawatan seterusnya diserap masuk ke dalam jawatan berpencen. Namun begitu, terdapat perbezaan dalam tempoh percubaan bagi anggota perkhidmatan awam yang disahkan dalam perkhidmatan tetapi kemudian dilantik pula ke dalam jawatan lain. Hal ini kerana tempoh percubaan yang diberikan kepada anggota perkhidmatan awam berkenaan sebelum disahkan dalam jawatan yang baharu lebih singkat iaitu hanya mengambil masa selama satu tahun sahaja.

Semasa berada dalam tempoh percubaan, anggota perkhidmatan awam diwajibkan oleh syarat-syarat perkhidmatan masing-masing untuk lulus dalam peperiksaan tertentu sebelum dipertimbangkan untuk disahkan jawatan pada penghujung tempoh percubaan tersebut. Hal ini bermakna bahawa terdapat peperiksaan yang bukan sahaja diadakan untuk menilai tahap pengetahuan anggota perkhidmatan awam tetapi mereka diwajibkan lulus sebelum dipertimbangkan untuk pengesahan dalam jawatan. Antara peperiksaan penting yang dilaksanakan adalah peperiksaan bahasa Melayu dan peperiksaan undang-undang yang diadakan dua kali setahun bagi memberi peluang dan kesempatan kepada pegawai-pegawai untuk lulus peperiksaan tersebut. ${ }^{46}$ Ringkasnya, peperiksaan yang diadakan dua kali setahun bukan sahaja bertujuan untuk memberi peluang kepada anggota perkhidmatan awam yang tidak berjaya lulus dalam peperiksaan pertama untuk mengambil semula peperiksaan kali kedua tetapi juga membuka ruang supaya anggota perkhidmatan awam benar-benar mempelajari dan memahami subjek berkenaan supaya dapat dipraktikkan sepanjang tempoh perkhidmatannya.

Berdasarkan penelitian yang dibuat berkenaan dengan peperiksaan untuk Bahasa Melayu sebenarnya terdapat tiga peringkat peperiksaan iaitu Darjah I, Darjah II dan Darjah III seperti berikut:

i). Peperiksaan Bahasa Melayu Darjah I tanpa jawi mengandungi:

(a) Terjemahan dari bahasa Melayu ke bahasa Inggeris

(b) Terjemahan dari bahasa Inggeris ke bahasa Melayu

(c) Kertas Am mengenai tatasusila dan adat resam orang Melayu dan sejarah Tanah Melayu

(d) Peperiksaan lisan

Sementara itu, bagi peperiksaan bahasa Melayu Darjah I termasuk jawi pula mengandungi semua a, b, c dan d tetapi terdapat tambahan satu kertas lain iaitu pemindahan tulisan daripada tulisan jawi kepada tulisan rumi dan sebaliknya.

ii). Peperiksaan Bahasa Melayu Darjah II termasuk jawi mengandungi a, b, c dan d seperti dalam Peperiksaan Bahasa Melayu Darjah I dan satu kertas lain iaitu pemindahan tulisan dari tulisan Jawi ke tulisan rumi dan sebaliknya.

iii). Peperiksaan Bahasa Melayu Darjah III pula mengandungi perkara-perkara seperti berikut:

(a) Terjemahan dari bahasa Melayu ke bahasa Inggeris

(b) Terjemahan dari bahasa Inggeris ke bahasa Melayu

(c) Nahu, peribahasa dan kesusasteraan

(d) "The Malays" - kertas berkenaan dengan kehidupan orang-orang Melayu, tatasusila dan adat resam, perusahaan orang Melayu, sejarah Tanah Melayu, unsur undang-undang agama Islam dan perkara-perkara umum yang mengambil perhatian dalam masyarakat Melayu.

(e) Karangan

(f) Peperiksaan lisan 
Berdasarkan turutan peperiksaan bahasa Melayu yang diadakan mengikut darjah tersebut, seseorang calon wajib lulus Darjah I sebelum boleh memasuki Darjah II dan mesti lulus dalam Darjah II untuk membolehkannya mengambil peperksaan Darjah III. Biasanya pelantikan anggota perkhidmatan awam ke Bahagian I dalam Perkhidmatan Am, mewajibkan seseorang calon untuk lulus sekurang-kurangnya bahasa Melayu Darjah I tanpa jawi. Namun begitu, anggota perkhidmatan awam berbangsa Melayu biasanya dikecualikan dari mengambil peperiksaan bahasa Melayu tersebut kerana hampir semua orang Melayu yang dilantik ke dalam perkhidmatan awam mempunyai sekurang-kurangnya kelulusan rendah dalam bahasa Melayu. Bagi anggota perkhidmatan awam bukan Melayu pula, syarat-syarat perkhidmatannya memerlukan mereka untuk lulus peperiksaan bahasa Melayu Darjah II dan hendaklah lulus kertas "The Malays" yang terkandung dalam peperiksaan bahasa Melayu Darjah III. ${ }^{47}$ Situasi tersebut menunjukkan terdapat kelonggaran bagi orang berbangsa Melayu dalam peperiksaan bahasa Melayu tetapi sebaliknya bagi anggota perkhidmatan awam bukan Melayu yang dikehendaki supaya lulus dalam peperiksaan bahasa Melayu bagi ketiga-tiga darjah tersebut. Jika diteliti, sebenarnya dasar sedemikian memberikan impak yang positif kepada kualiti perkhidmatan awam khususnya kepada anggota perkhidmatan yang bukan berbangsa Melayu memandangkan banyak urusan yang melibatkan warga tempatan dijalankan dalam bahasa Melayu. Hal ini terbukti apabila PTM mendapat kemerdekaan pada tahun 1957, kerajaan meluluskan Perkara 152 (1) menjadi undang-undang untuk menguatkuasakan bahawa bahasa Melayu ialah bahasa kebangsaan bagi Persekutuan. $^{48}$ Dalam Perkara 152 (1) disebut dengan jelas bahawa bahasa kebangsaan adalah bahasa Melayu dan akan kekal seperti itu, seperti yang diperuntukkan oleh parlimen dengan peruntukan bahawa:

a). tidak akan ada seorang pun yang akan dihalang dari menggunakan (kecuali hal hal rasmi) atau mengajar atau mempelajari bahasa-bahasa lain dan

b). tidak ada sebarang peruntukan dalam perkara ini yang boleh mengganggu hak kerajaan Persekutuan atau sebarang kerajaan negeri untuk memelihara dan memperkembangkan penggunaan dan pengkajian bahasa komuniti lain. ${ }^{49}$

Ternyata penggubalan Perkara 152 (1) bukan sahaja memberikan taraf kebangsaan tetapi meletakkan bahasa Melayu secara automatik menjadi bahasa perantaraan untuk digunakan dalam semua maksud rasmi urusan pentadbiran kerajaan. Namun, semua bahasa lain walaupun boleh diajar dan dipelajari tetapi hanya boleh digunakan untuk tujuan "selain daripada maksud rasmi". Dengan erti kata lain, walaupun bahasa Melayu menjadi bahasa kebangsaan, perlembagaan tidak melarang sesiapa pun mengajar dan mempelajari bahasa-bahasa lain. Perlembagaan juga tidak melarang bahasa-bahasa lain digunakan untuk maksud-maksud yang bukan rasmi. Di samping itu, perlembagaan juga tidak menyentuh apa-apa hak yang dipunyai oleh kerajaan Persekutuan dan kerajaan negeri untuk mengekalkan dan mengamalkan penggunaan dan pembelajaran bahasa-bahasa kaum lain dalam persekutuan ini. Oleh itu, jelaslah bahawa pentingnya anggota perkhidmatan awam khususnya yang bukan berbangsa Melayu untuk mempelajari dan menguasai bahasa Melayu bagi melancarkan tugas yang diamanahkan kepada mereka.

Sementara itu, anggota perkhidmatan awam yang gagal dalam peperiksaan bahasa Melayu akan dikenakan denda berupa penangguhan kenaikan gaji yang biasanya berbeza dari enam bulan hingga dua tahun. Tempoh percubaan bagi anggota perkhidmatan ini hanya akan disambung sekiranya terdapat alasan yang munasabah 
berkenaan sebab kegagalannya dalam peperiksaan ataupun ketua pejabat tempat anggota perkhidmatan tersebut berkhidmat berpendapat bahawa anggota itu berkemungkinan akan lulus dalam peperiksaan jika tempoh percubaannya disambung. Namun demikian, sekiranya sambungan tempoh percubaan dengan penangguhan kenaikan gaji dikenakan kepada seseorang anggota, ia akan menyebabkan anggota terbabit kehilangan taraf yang kanan (seniority). ${ }^{50}$ Hal ini menunjukkan dengan jelas bahawa anggota perkhidmatan awam perlu lulus peperiksaan bahasa Melayu yang dilaksanakan kerajaan supaya dapat menikmati kenaikan gaji dan kenaikan pangkat. Pada masa yang sama, prasyarat tersebut dapat membantu kerajaan melahirkan anggota perkhidmatan awam yang mahir berbahasa Melayu yang seterusnya amat berguna untuk melancarkan urusan antara kerajaan dan rakyat.

Seterusnya, setelah seseorang anggota perkhidmatan awam diterima dalam jawatan berpencen, menurut Peraturan 16, Peraturan-peraturan Pencen, 1957, anggota perkhidmatan awam tersebut dikehendaki membuat pilihan sama ada memilih untuk menerima pencen penuh atau menerima pencen yang disusutkan. Pilihan pencen berkenaan hendaklah dibuat sebelum persaraan mereka dikuatkuasakan kerana sekiranya anggota perkhidmatan awam gagal untuk berbuat demikian pemberianawal faedah persaraan akan terganggu. ${ }^{51} \mathrm{Hal}$ ini bermakna, anggota perkhidmatan awam akan berhadapan dengan kesulitan untuk menerima lebih awal faedah persaraan tersebut.

\section{Kadar Pencen dan Elaun Sara Hidup Anggota Perkhidmatan Awam}

Perbincangan mengenai kadar pencen dan elaun sara hidup anggota perkhidmatan awam merupakan salah satu aspek yang perlu diteliti untuk memahami kepentingannya dalam sistem saraan atau pencen bagi anggota perkhidmatan awam di PTM. Walaupun terdapat perbezaan antara sistem saraan dan persaraan tetapi keduadua perkara ini sebenarnya saling berkait rapat dan melengkapi antara satu sama lain. Hal ini kerana pencen dan elaun sara hidup adalah faedah yang diperoleh anggota perkhidmatan awam selepas mereka bersara daripada perkhidmatan awam. Oleh itu, perubahan yang berlaku dalam sistem saraan adalah berkait rapat dengan faedahfaedah persaraan bagi anggota perkhidmatan awam.

Dengan kata lain, sebarang perubahan yang berlaku dalam sistem saraan akan memberi kesan terhadap kadar pencen dan elaun sara hidup bagi anggota perkhidmatan awam. Memandangkan tempoh perbincangan terbahagi kepada dua era iaitu sebelum dan selepas PTM mencapai kemerdekaan wajarlah untuk dihuraikan terlebih dahulu kadar pencen dan elaun anggota perkhidmatan awam sebelum merdeka. Kadar pencen dan elaun yang diterima oleh anggota perkhidmatan awam pada peringkat awal semasa PTM di bawah pentadbiran British menunjukkan bahawa pesara kerajaan yang berkelayakan hanya diberikan pencen mengikut kelayakan masing-masing. ${ }^{52}$ Hanya selepas Perang Dunia Kedua berakhir, pesara-pesara awam diberikan bantuan kewangan atas permohonan masing-masing yang dibuat kepada Residen British. ${ }^{53}$ Apa yang menariknya di sini adalah pesara-pesara awam juga turut menerima elaun sara hidup sebanyak 20 peratus berdasarkan kepada gaji tahunannya. Hal ini jelas terbukti berdasarkan rekod yang menyatakan bahawa elaun sara hidup disusun buat pertama kalinya pada tahun 1946 di bawah Malayan Union Secretariat Circular No.133/46 yang kemudiannya dikuatkuasakan pada 1 April $1946 .{ }^{54}$ Perkara tersebut menjelaskan bahawa British turut memberi perhatian terhadap pemberian elaun sara hidup yang dibuat bertujuan untuk memperbaiki taraf hidup pesara-pesara awam supaya mereka dapat menikmati kehidupan yang lebih berkualiti selepas bersara daripada perkhidmatan awam. 
Seterusnya, bermula pada 1 Ogos 1947 sehingga 31 Disember 1951, bayaran pencen bulanan yang diterima oleh pesara-pesara awam mengandungi pencen pokok, elaun sara hidup yang dibayar berdasarkan pencen pokok, elaun penggenap 'complementary' dan elaun pelengkap 'suplementary'. Kemudian, antara 1 Januari 1952 sehingga 31 Disember 1954, bayaran bulanan yang diterima oleh pesara-pesara awam merangkumi pencen pokok, elaun sara hidup dan elaun pelengkap 'suplementary'. Anggota yang bersara daripada perkhidmatan awam pada atau selepas 1 Januari 1955 sehingga 21 Disember 1969 pula akan menerima bayaran bulanan pencen yang mengandungi pencen pokok dan elaun sara hidup. ${ }^{55}$ Seterusnya, pada tahun 1970, satu pekeliling dikeluarkan dikenali sebagai Pekeliling Perkhidmatan Bil. 7 tahun 1970 yang dikuatkuasakan pada 1 Januari 1970. Menerusi pekeliling tersebut, bayaran bulanan yang diterima oleh pesara-pesara awam turut dipinda mengikut ketetapan yang terdapat dalam pekeliling tersebut iaitu bergantung kepada pilihan sistem gaji yang diberikan kepada pekerja tetap dalam Bahagian I, II dan III. ${ }^{56} \mathrm{Hal}$ ini bermakna bahawa pemberian pencen selepas 1 Januari 1970 akan bergantung kepada pilihan sistem gaji yang dipilih oleh seseorang anggota perkhidmatan awam manakala kadar bayaran pencen atau elaun yang dianugerahkan kepada pesara-pesara kerajaan di PTM bergantung kepada tarikh dan tahun persaraan mereka.

Sementara itu, menyentuh berkenaan kadar pencen yang akan diberikan kepada anggota perkhidmatan awam di PTM selepas kemerdekaan pada 31 Ogos 1957 dapat dilihat melalui Peraturan 5 dalam Peraturan-peraturan Pencen 1957, yang menetapkan setiap pegawai yang memegang jawatan berpencen dalam perkhidmatan awam persekutuan dan mana-mana perkhidmatan awam kerajaan selama sepuluh tahun layak apabila bersara diberikan pencen mengikut kadar satu per enam ratus (1/600) pendapatan berpencen tahunannya. ${ }^{57}$ Bayaran semua kos perbelanjaan untuk pembayaran pencen kepada anggota perkhidmatan awam di PTM akan ditanggung oleh kerajaan pusat.

Pada tahun 1967, berlaku perubahan pada kadar pencen yang diberikan kepada anggota perkhidmatan awam di PTM apabila laporan yang dibuat oleh Suruhanjaya diRaja Suffian dikemukakan untuk pertimbangan kerajaan. Dalam Laporan Suruhanjaya diRaja Suffian terdapat syor untuk membayar pencen mengikut kadar satu perlapan ratus (1/800) pendapatan berpencen tahunan seseorang anggota perkhidmatan awam. Syor tersebut dibuat berdasarkan pandangan bahawa perubahan saiz dan pertambahan jumlah anggota perkhidmatan awam akibat daripada perkembangan pesat ekonomi akan menyebabkan kerajaan tidak berkemampuan untuk membayar pencen mengikut kadar 1/600. Oleh itu, Suruhanjaya diRaja Suffian berpendapat adalah lebih baik kadar tersebut diubah menjadi $1 / 800 .{ }^{58}$ Walaupun sebenarnya ia bertujuan untuk mengelakkan bebanan kerajaan menampung pembayaran pencen kepada anggota perkhidmatan awam tetapi syor berkenaan memperlihatkan penurunan kadar pencen yang akan diterima oleh pesara-pesara awam. Oleh itu, pelaksanaan sistem kadar pencen 1/800 menjarakkan lagi jurang perbezaan faedah bulanan yang diterima oleh pesara-pesara awam.

Secara umumnya, perkiraan pencen bagi anggota perkhidmatan awam yang bersara adalah mengikut kadar separuh gaji akhir sebelum seseorang pegawai kerajaan tersebut bersara. Setiap anggota perkhidmatan awam akan berkelayakan mendapat perubahan pencen setiap kali pegawai kerajaan yang berkhidmat mendapat perubahan gaji. ${ }^{59}$ Sebenarnya pencen yang diterima oleh pesara adalah kecil iaitu kurang daripada separuh gaji dan elaun-elaun yang diterima mereka ketika berkhidmat. Selain itu, pencen yang diterima juga adalah tetap iaitu tidak akan bertambah dari setahun ke setahun sehinggalah berlaku semakan gaji pegawai- 
pegawai kerajaan. Hal ini bermakna bahawa kadar pencen tidak akan ada kenaikan tahunan seperti yang diperoleh oleh pegawai-pegawai kerajaan yang berpeluang untuk mendapat kenaikan pangkat dari semasa ke semasa. ${ }^{60}$

\section{Isu dalam Umur Pencen Bagi Anggota Perkhidmatan Awam}

Terdapat satu lagi aspek yang perlu diberikan perhatian dalam perbincangan mengenai sistem saraan bagi anggota perkhidmatan awam di PTM iaitu berkenaan umur persaraan. Semasa PTM di bawah pentadbiran British, seseorang anggota perkhidmatan awam wajib bersara pada umur 55 tahun tetapi boleh memilih untuk bersara apabila berumur 50 tahun. $^{61}$ Namun demikian, seseorang anggota perkhidmatan awam tidak boleh bersara sebelum mencapai umur 45 tahun bagi anggota tertentu ataupun berumur 50 tahun kecuali persaraan itu disebabkan oleh faktor seperti keadaan kesihatan yang kurang baik. Anggota perkhidmatan awam yang ingin meninggalkan perkhidmatan hanya boleh berbuat demikian melalui cara meletakkan jawatan. Walaupun begitu, sekiranya seseorang anggota perkhidmatan awam meletakkan jawatan sebelum mencapai umur persaraannya tanpa faktor seperti masalah kesihatan, semua faedah persaraan yang tertakluk dalam perkhidmatannya sebelum ini akan dilucutkan semua sekali. ${ }^{62}$ Hal ini juga bermaksud bahawa anggota tersebut tidak akan mendapat sebarang faedah persaraan atau tidak menerima sebarang bayaran daripada kerajaan.

Oleh itu, pencen diberikan kepada seseorang anggota perkhidmatan awam yang berkelayakan apabila mereka bersara seperti berikut:

a. Mencapai had umur yang dihadkan

b. Bersara atas sebab kesihatan

c. Bersara atas sebab perkahwinan, jika kakitangan wanita

d. Bersara atas pemansuhan jawatan

e. Bersara atas pengurangan kakitangan awam

f. Bersara atas kepentingan negara

g. Bersara atas kepentingan awam

Sekiranya seseorang anggota perkhidmatan awam bersara disebabkan pilihan a hingga $f$, faedah persaraan diberi mengikut sepenuh kelayakannya. Akan tetapi, jika anggota itu bersara atas sebab perkara g, faedah persaraan yang diberikan padanya akan bergantung kepada sebab persaraannya atau bergantung kepada corak kesalahannya. Dengan kata lain, jika kesalahan yang dilakukan memerlukan hukuman berat, faedah persaraan akan disusutkan seimbang dengan kesalahan yang dilakukan anggota terbabit. Susutan yang dikenakan itu pula bergantung kepada kesalahan yang dilakukan antara lima peratus hingga seratus peratus. ${ }^{63}$ Berdasarkan penjelasan, didapati pelbagai pertimbangan yang akan dilakukan sebelum memberikan faedah persaraan atau pencen kepada anggota perkhidmatan awam untuk memastikan penerima faedah persaraan dan pencen tersebut memenuhi kelayakan yang disyaratkan oleh kerajaan.

Sementara itu, perlu juga dijelaskan bahawa terdapat perbezaan dari segi umur persaraan antara anggota perkhidmatan awam lelaki dan wanita. Sebelum tahun 1959, had umur bersara atau pencen bagi anggota perkhidmatan awam wanita sama ada yang berkhidmat sebagai anggota perkhidmatan yang bergaji bulan merangkumi Bahagian I hingga Bahagian IV ataupun yang bergaji hari ditetapkan pada umur 45 tahun. Had umur persaraan sedemikan ditetapkan oleh Harold Goodhew Turner yang pada masa itu menyandang jawatan sebagai Ketua Pengarah Perkhidmatan Awam di PTM. ${ }^{64}$ Walaupun anggota wanita dalam perkhidmatan awam secara automatik bersara apabila mencapai umur 45 tahun tetapi mereka turut diberikan pilihan untuk 
bersara pada umur sebelum atau selepas 45 tahun dengan pemberian ganjaran atau elaun persaraan. ${ }^{65}$ Sementara itu, bagi anggota wanita yang memilih untuk bersara pada umur 55 tahun pula tertakluk kepada ketua jabatan tempatnya berkhidmat sama ada mereka berpuas hati terhadap kecekapan pegawai wanita tersebut. Hal ini menunjukkan bahawa anggota wanita dalam perkhidmatan awam diberikan kelonggaran untuk bersara lebih awal daripada umur 45 tahun yang dihadkan pada ketika itu. Ketetapan ini dibuat kerana kebanyakan anggota wanita yang berkahwin akan lebih fokus terhadap keluarga masing-masing menyebabkan timbul kebimbangan bahawa mereka tidak akan dapat melaksanakan tugasnya dengan baik. Oleh itu, anggota wanita dalam perkhidmatan awam perlu menunjukkan kecekapan dalam menjalankan tugas kepada ketua jabatan sekiranya hendak bersara pada umur yang sama seperti anggota lelaki iaitu pada usia 55 tahun. Keadaan ini sudah tentu mewujudkan cabaran yang lebih besar kepada mereka untuk menunjukkan keupayaannya menjalankan tugas sebagaimana anggota lelaki.

Walau bagaimanapun, berlaku perubahan menarik dalam soal umur persaraan bagi anggota wanita dalam perkhidmatan awam semasa perkhidmatan awam berada di bawah teraju pimpinan Tan Sri Ahmad Haji Husin sebagai Ketua Pengarah Perkhidmatan Awam bermula pada 5 Oktober 1959 sehingga 1 Mac 1963. ${ }^{66}$ Perubahan yang dimaksudkan ialah pelanjutan had tempoh umur bersara bagi anggota wanita daripada umur 45 tahun kepada umur 55 tahun tetapi pada masa yang sama, wanita tersebut juga boleh memilih tempoh persaraan pada bila-bila masa dalam lingkungan umur 45 sehingga 55 tahun. ${ }^{67}$ Perubahan tersebut dilihat sebagai sesuatu yang positif memandangkan PTM yang masih baru mencapai kemerdekaan sudah tentu memerlukan lebih banyak anggota wanita dalam perkhidmatan awam awam untuk melaksanakan urusan pentadbiran negara dan juga menjalankan fungsi perkhidmatan awam yang semakin membesar. Selain itu, situasi ini juga dilihat sebagai peluang keemasan kepada golongan wanita untuk membuktikan kemampuan mereka dalam memberikan perkhidmatan yang cemerlang. Di samping itu, ia juga boleh dilihat sebagai salah satu usaha kerajaan untuk memberikan anggota wanita dan anggota lelaki faedah dan manfaat yang adil dan saksama bagi menjamin perkhidmatan awam yang cekap dan berkualiti. Namun demikian, pada tahun 1968, satu rang undang-undang yang dikenali sebagai The Pensions (Amendment) Act, 1968 dicadangkan bertujuan untuk memperketatkan undang-undang yang menetapkan bahawa seorang anggota wanita dalam perkhidmatan awam yang diambil bertaraf pencen sebelum atau selepas akta ini dikuatkuasakan tidak akan diberikan ganjaran sekiranya berhenti kerja selepas berkahwin. Walau bagaimanapun, rang undangundang ini tidak diluluskan. ${ }^{68}$

Di samping itu, terdapat satu lagi perkara penting berlaku berkaitan dengan pesara-pesara awam di PTM iaitu apabila terdapat pengambilan pegawai-pegawai keselamatan, polis dan askar yang bersara untuk berkhidmat semula dalam perkhidmatan awam. ${ }^{69}$ Tindakan ini merupakan satu langkah untuk menjamin keselamatan negara daripada sebarang ancaman akibat konfrontasi dengan negara jiran khususnya Indonesia. Walaupun wujud persoalan berkenaan kemampuan anggota keselamatan yang telah bersara tersebut untuk menjalankan tugas sebagai pelindung kepada sebarang ancaman keselamatan negara tetapi sebenarnya penglibatan mereka penting bagi meningkatkan lagi kemahiran anggota keselamatan yang sedia ada pada ketika itu. Jika diteliti kebanyakan anggota keselamatan yang bersara mempunyai pengalaman yang luas berhadapan dengan pelbagai ancaman musuh ketika Perang Dunia Kedua dan semasa keganasan komunis di PTM. Oleh itu, pengalaman mereka amat berguna untuk dikongsi dan dijadikan panduan kepada 
anggota keselamatan yang baharu dalam menghadapi sebarang krisis yang boleh menggugat keselamatan negara.

\section{Kesimpulan}

Berdasarkan perbincangan, dapatlah disimpulkan bahawa sistem saraan bagi anggota perkhidmatan awam di PTM mengalami perubahan dan penambahbaikan. Di bawah pentadbiran British, kajian terhadap semakan gaji yang dilaporkan oleh Laporan Trusted 1947 dan Laporan Suruhanjaya Benham 1950 menyebabkan anggota perkhidmatan awam menerima kenaikan tangga gaji. Selain itu, anggota wanita dalam perkhidmatan awam juga mendapat manfaat kenaikan gaji yang sama seperti anggota lelaki. Seterusnya, di bawah pentadbiran kerajaan PTM, kajian semula gaji dijalankan dan hasilnya diterbitkan dalam Laporan Suffian 1967. Berdasarkan kajian tersebut, tangga gaji terutama anggota perkhidmatan awam di peringkat rendah dan syaratsyarat perkhidmatan telah ditambahbaik. Apa yang menariknya, aspek pencen ditambah baik menyebabkan anggota perkhidmatan awam mendapat faedah persaraan yang lebih baik. Oleh itu, jelaslah bahawa hasil laporan dan cadangan yang dikemukakan oleh ketiga-tiga suruhanjaya semakan gaji tersebut membantu kerajaan merangka sistem gaji yang lebih baik supaya kelak anggota perkhidmatan awam akan mendapat faedah persaraan yang baik apabila bersara daripada perkhidmatan masingmasing.

Nota

1 Istilah Persekutuan Tanah Melayu terus digunakan kerana skop kajian hanya merangkumi perbincangan di negeri-negeri yang terdapat di Semenanjung Malaysia sahaja. Dengan kata lain, istilah Persekutuan Tanah Melayu dalam artikel ini diguna pakai kerana dalam Perjanjian Persekutuan Malaysia 1963 dinyatakan bahawa semenanjung Malaysia dirujuk sebagai Persekutuan Tanah Melayu. Di samping itu, ia juga selari dengan Perjanjian Persekutuan Tanah Melayu, 1948 dan Perjanjian Persekutuan Tanah Melayu, 1957 yang merujuk negeri Johor, Pahang, Negeri Sembilan, Selangor, Kedah, Perlis, Kelantan, Terengganu, Perak, Melaka dan Pulau Pinang sebagai negeri-negeri yang terkandung dalam Persekutuan Tanah Melayu. Oleh itu, memandangkan huraian dalam perbincangan artikel ini hanya menyentuh perkembangan perkhidmatan awam di semenanjung Malaysia sahaja menyebabkan pendirian diambil untuk mengekalkan penggunaan istilah Persekutuan Tanah Melayu.

2 Burhanudin Halim, Mohd Faidzul Fahmi Md Nor dan Mohd Nazen Saiden, Kuasa Tak Ketara, Pengaruh Tak Diheboh: Institusi KPPA, Putrajaya: Jabatan Perkhidmatan Awam, 2009, h. 38.

3 Semakan terhadap gaji anggota perkhidmatan awam di PTM sebenarnya telah pun wujud apabila Laporan Bucknill 1919 diterbitkan mengandungi syor-syor berkenaan gaji asas (basic salaries), emolumen dan syarat perkhidmatan bagi pegawai-pegawai kanan di Tanah Melayu dan Singapura. Selain itu, terdapat lagi satu laporan berkenaan hal gaji bagi Junior Officers yang dikenali sebagai Subordinate Services Salaries Committee of 1920. Melalui skim gaji yang disyorkan dalam laporan inilah menyebabkan elaun kos sara hidup turut diberikan kepada anggota perkhidmatan awam. Namun demikian, elaun kos sara hidup tersebut ditarik semula pada tahun 1931 atas sebab keadaan ekonomi yang tidak menentu pada masa itu sehingga menyukarkan kerajaan membayar elaun kos sara hidup kepada anggota perkhidmatan awam. Penjelasan lanjut sila rujuk Report of the Public Services, Salaries Commissions of Malaya 1947, Kuala Lumpur: Malayan Union Government Press, 1947, h. 2.

The Salaries Commissions Report officially reliased today (9 December 1947), it recommends new Salaries scales and cost of living and expatriations allowances, new schemes for locally 
trained men and the abolition of differences in salary between locally trained men and men recruits from oversea. The Straits Times, 9 Disember 1947, h. 1.

The Commission will be composed of: Sir Harry Trusted (Chairman), Mr. C. E Tilney (Ceylon Civil Service), Mr. H, Basten (Chairman, Singapore and Penang Harbour Boards), Mr. Wu Chong Jin (Patrner in Walters \& Co Avocates and Solicitors Singapore), Dato' Mahmud bin Mat (Malayan Civil Service, Seremban), Mr. Baghwan Singh (Member Indian Chamber of Commerce, Kuala Lumpur), Mr. A. Inglis (P. W.D. Singapore) and Mr. M. J. Heyward (Malayan Civil Service, Kuala Lumpur). Indian Daily Mail, 19 April 1947, h. 4, Morning Tribune, 19 April, 1947, h. 1 dan Malayan Tribune, 19 April 1947, h. 5. Report of the Public Services, Salaries Commissions of Malaya 1947, h. 1, Indian Daily Mail, 19 April 1947, h. 4, Morning Tribune, 19 April, 1947, h. 1 dan Malayan Tribune, 19 April 1947, h. 5.

Indian Daily Mail, 9 Disember 1947, h. 4.

Report of the Public Services, Salaries Commissions of Malaya 1947, h. 12.

Burhanuddin Halim, Mohd Faidzul Fahmi Md Nor dan Muhammad Nazari Saidan, Kuasa Tak Ketara Pengaruh Tak Diheboh, h. 39.

Dr. F.C. Benham merupakan penasihat ekonomi kepada Commissioner General.

Wan Mansor Abdullah, Service Par Excellence, Kuala Lumpur: Percetakan Nasional Malaysia Berhad, (PNMB), 2004, h. 306-307.

Ibid., h. 307.

Report of The Special Committee on Salaries in the Federation of Malaya, September 1950, Kuala Lumpur: Government Printer, 1950, h. 1.

Wan Mansor Abdullah, Service Par Excellence, h. 307-308.

Report of The Special Committee on Salaries in the Federation of Malaya, September 1950, h. 3.

Ibid., h. 7 .

Ibid., hlm. 8 .

Berita Harian, 22 Mac 1964, h. 4.

Ibid.

Tun Mohamed Suffian bin Hashim merupakan ketua hakim negara. Beliau telah mendapat pendidikan awal di Sekolah Melayu Lenggong dan Sekolah Clifford di Perak. Kemudian beliau melanjutkan pelajarannya dalam bidang undang-undang di England pada tahun 1936 sebagai 'Queen's Scholar' dan lulus sebagai seorang peguam pada tahun 1940. Tun Suffian telah memulakan perkhidmatan di TM pada tahun 1948 apabila beliau dilantik sebagai seorang Majisteret di samping sebagai Harbour Master di Melaka. Selain itu, beliau juga pernah berkhidmat di Pahang dan Johor serta sebagai Peguamcara Kanan Persekutuan di Kuala Lumpur sebelum beliau dilantik sebagai Peguamcara Negara Malaya pada tahun 1959. Pada tahun 1968, beliau dilantik sebagai Hakim Mahkamah Tinggi Persekutuan dan pada tahun 1973, Tun Suffian telah dilantik sebagai Hakim Besar Malaya. Seterusnya, beliau telah dilantik sebagai Ketua Hakim Negara yang ketiga. Sumbangan Tun Suffian dalam bidang undang-undang dan kehakiman di negara ini sungguh besar. Pada tahun 1965, beliau dilantik menjadi Pengerusi Suruhanjaya Gaji yang dikenali sebagai 'Suruhanjaya di Raja Suffian' dengan peruntukan-peruntukan perkhidmatan awam yang baru termasuk mengenai mengurangkan kemudahan seperti 'free world tour' untuk pegawai-pegawai kerajaan. Duli Yang Maha Mulia Seri Paduka Baginda Yang di Pertuan Agong turut telah mengurniakan darjah Seri Setia Mahkota pada tahun 1975 sebagai satu pengiktirafan terhadap sumbangan Tun Suffian kepada negara ini. Sumber dipetik daripada http://mahathir.com/malaysia/speeches/1982/1982-11-11.php. 7 Mei 2014.

Kedua Jawatankuasa Khas Mengkaji Dasar-dasar Faedah Persaraan Pekerja-pekerja Dalam Perkhidmatan Awam dan Badan-badan Berkanun, Penggal I, November, 1973, h. 27.

Burhanuddin Halim, Mohd Faidzul Fahmi Md Nor dan Muhammad Nazari Saidan, Kuasa Tak Ketara Pengaruh Tak Diheboh, h. 39.

Berita Harian, 19 Disember 1967, h. 1.

Burhanuddin Halim, Mohd Faidzul Fahmi Md Nor dan Muhammad Nazari Saidan, Kuasa Tak Ketara Pengaruh Tak Diheboh, h. 26.

Ibid., h. 28.

Report of the Royal Commission on the Revision of Salaries and Condition of Service in the Public Service, July 1967, Kuala Lumpur: Jabatan Cetak Kerajaan, 1969, h. 36.

Ibid. 
Lapuran Kedua Jawatankuasa Khas Mengkaji Dasar-dasar Faedah Persaraan Pekerjapekerja dalam Perkhidmatan Awam dan Badan-badan Berkanun, Penggal I, November, 1973, h. 31 .

Report of the Royal Commission on the Revision of Salaries and Condition of Service in the Public Service, July 1967, h. 36.

Lapuran Kedua Jawatankuasa Khas Mengkaji Dasar-dasar Faedah Persaraan Pekerjapekerja Dalam Perkhidmatan Awam dan Badan-badan Berkanun, Penggal I, November, 1973 , h. 31.

Ibid., h. 31-32.

Ibid., h. 32.

Report of the Royal Commission on the Revision of Salaries and Condition of Service in the Public Service, July 1967, h. 41.

Lapuran Kedua Jawatankuasa Khas Mengkaji Dasar-dasar Faedah Persaraan Pekerjapekerja Dalam Perkhidmatan Awam dan Badan-badan Berkanun, h. 30.

Ibid., h. 41.

Ibid., h. 30.

Burhanuddin Halim, Mohd Faidzul Fahmi Md Nor dan Muhammad Nazari Saidan, Kuasa Tak Ketara Pengaruh Tak Diheboh, h. 36.

Ibid., h. 41.

Lapuran Kedua Jawatankuasa Khas Mengkaji Dasar-dasar Faedah Persaraan Pekerjapekerja Dalam Perkhidmatan Awam dan Badan-badan Berkanun, h. 19-20.

The Pensions Ordinance, 1951, Published in Supplement to the Federation of Malaya Government Gazatte of February 27, 1951, No. 5, Vol. IV, Notification Federal, No. 491.

Lapuran Kedua Jawatankuasa Khas Mengkaji Dasar-dasar Faedah Persaraan Pekerjapekerja Dalam Perkhidmatan Awam dan Badan-badan Berkanun, h. 21.

Ibid.

Nik Abdul Rashid Majid, Pencen Di Bawah Perlembagaan, Mac 1987, Arkib Negara Malaysia.

Ibid.

Ibid.

Penyata Tahunan Surohanjaya Perkhidmatan Awam Malaysia, 1961, Kuala Lumpur: Penchetak Kerajaan, 1964, h. 7.

Ibid., h. 8.

Tun Mohamed Suffian bin Hashim, Mengenal Perlembagaan Malaysia, Kuala Lumpur: Dewan Bahasa dan Pustaka, 1987, h. 441.

Malaysia, Perlembagaan Persekutuan (Terjemahan), Jabatan Peguam Negara, Kuala Lumpur: Jabatan Cetak Kerajaan, 1972, h. 171-172.

Penyata Tahunan Surohanjaya Perkhidmatan Awam Malaysia, 1961, h. 8-9.

Lapuran Kedua Jawatankuasa Khas Mengkaji Dasar-dasar Faedah Persaraan Pekerjapekerja Dalam Perkhidmatan Awam dan Badan-badan Berkanun, h. 23.

Laporan Pertama Jawatankuasa Khas Mengenai Kedudukan Pencen Pesara-pesara Kerajaan, Februari 1973, h. 10.

Ibid.

Ibid.

Ibid., h. 15-17.

Pekeliling Perkhidmatan Bil. 7 Tahun 1970, Perubahan Gaji dan Syarat-syarat Perkhidmatan Bagi Pekerja-pekerja dalam Bahagian I, II dan III dalam Perkhidmatan Awam di Malaysia Barat, Kuala Lumpur: Jabatan Cetak Kerajaan, 1970, h. 21-22.

Laporan untuk 1968-1970, Persidangan Perwakilan Kongres Kesatuan Pekerja-pekerja di dalam Perkhidmatan Awam kali ke 11, 18-20 Disember 1970 bertempat di Dewan Persatuan Pemandu Puteri Selangor, Kuala Lumpur, h. 91.

Lapuran Kedua Jawatankuasa Khas Mengkaji Dasar-dasar Faedah Persaraan Pekerjapekerja Dalam Perkhidmatan Awam dan Badan-badan Berkanun, h. 31.

"Persatuan Pesara Kerajaan Malaysia", Berita Pesara, Volume 6, No. 1, 1995, h. 2.

Ibid., h. 5.

Nordin Selat, Satu Kajian Perkembangan Gaya Hidup Kelas Menengah Pentadbir Melayu, Kuala Lumpur: Jabatan Penerbitan Utusan Melayu (M) Berhad, 1976, h. 193.

Laporan untuk 1968-1970, Persidangan Perwakilan Kongres Kesatuan Pekerja-pekerja di dalam Perkhidmatan Awam kali ke 11, 18-20 Disember 1970, h. 91. 
Ibid., h. 22.

Harold Goodhew Turner dilahirkan pada 23 Disember 1906 di Gillingham, Kent. Beliau mendapat pendidikan di St. Olave's Trinity Collage, Cambridge dan memulakan perkhidmatannya di Tanah Melayu sebagai pegawai kadet kepada Commissioner Resettlement of Special Constables in Civil Life pada 22 Mac 1929. Seterusnya beliau telah berkhidmatan dengan cemerlang dalam beberapa jawatan sehingga ditawarkan jawatan sebagai Principal Establishment Officers pada tahun 1957 sehingga 1959. Maklumat lanjut sila rujuk Burhanuddin Halim, Mohd Faidzul Fahmi Md Nor dan Muhammad Nazari Saidan, Kuasa Tak Ketara Pengaruh Tak Diheboh, h. 57-61.

Ibid., h. 59.

Tan Sri Ahmad Haji Husin dilahirkan pada 29 Julai 1909 di Rompin, Pahang telah mendapat pendidikan awal di Kolej Melayu Kuala Kangsar, Perak dan merupakan pelajar cemerlang di kolej tersebut. Beliau menyertai Malayan Administrative Service (MAS) pada tahun 1927. Seterusnya, selepas memegang beberapa jawatan dalam perkhidmatan awam beliau telah dilantik sebagai Ketua Pegawai Perjawatan pada tahun 1959 sehingga 1963. Maklumat lanjut sila rujuk Burhanuddin Halim, Mohd Faidzul Fahmi Md Nor dan Muhammad Nazari Saidan, Kuasa Tak Ketara Pengaruh Tak Diheboh, h. 66-71. Ibid., h. 70.

Perbahathan Parlimen, Dewan Negara, Penyata Rasmi, 22 Oktober 1968, Johor Bharu: Jabatan Cetak Kerajaan, 1969, h. 142-144.

Burhanuddin Halim, Mohd Faidzul Fahmi Md Nor dan Muhammad Nazari Saidan, Kuasa Tak Ketara Pengaruh Tak Diheboh, h. 69. 